\title{
Högskolan bör driva kunskapsutvecklingen och utveckla handlingsförmågor för att möta de globala utmaningarna
}

\begin{abstract}
Akademin äger resurser som man hittills inte i tillräckligt hög grad nyttjat för att angripa världens långsiktiga och djupa ekologiska, ekonomiska och sociala problem. Den starkaste resursen är förmodligen studenterna. Men ett av de största problemen är att världen väljer att skjuta upp gemensamma lösningar till senare; högskolan med sin privilegierade ställning som samhällets kunskapsbank och kritiska granskare har en möjlighet att visa hur brådskande det är att finna och iscensätta sådana lösningar. Också $i$ sin uppgift som utbildarnas utbildare bör högskolan se till att de globala utmaningarna får en framskjuten plats $i$ alla utbildningar.
\end{abstract}

De stolta deviserna om demokrati och rättvisa gäller självklart inte bara Sverige eller Europa; de måste rimligen gälla hela världen. Extrem fattigdom i Afrika och förtryck i Kina är inte bara angelägenheter för afrikaner och kineser, lika lite som det är bara svenskarnas sak hur Sverige använder världens resurser, övergöder dess hav eller använder dess alltför billiga arbetskraft. Och bortsett från en moralisk plikt att hjälpa andra som har det sämre ställt, utgör de skriande orättvisorna och missförhållanden som brukar samlas under den något förskönande beteckningen "de globala utmaningarna" ett direkt hot mot våra liv och mot kommande generationer.

How to cite this book chapter:

Casson, A 2015 Högskolans ansvar: Principer för utveckling av den högre utbildningen. London: Ubiquity Press. DOI: http://dx.doi.org/10.5334/bap.f License: CC-BY 3.0 
Dessutom är de globala utmaningarna nära kopplade till de lokala utmaningarna. Dalarna kan nu mindre än någonsin dra sig tillbaka till sin egen enklav och sköta sitt. Jobben vid Kvarnsvedens pappersbruk påverkas direkt av hur många som köper och läser papperstidningar i hela Västeuropa, vilket i sin tur påverkas av bättre och billigare läsplattor, designade i västra USA och tillverkade i Asien med användning av sällsynta metaller från gruvor i Västafrika. Jobben vid Domnarvets järnverk försvinner på sikt om Kina lyckas ännu bättre med pris och kvalitet i sin produktion av specialstål. Det är väl ingen större förändring om skidsäsongen i Dalarna blir kortare på grund av den globala uppvärmningen men om långvarig torka, krig och förföljelse gör att människor i hundratusental ger sig iväg från sina hem i Somalia eller Syrien, skapar det ett nytt Borlänge, ett nytt Avesta, ett nytt Falun. Ett inflöde av nya medborgare från andra sidan jordklotet bidrar till en förnyelse och nödvändig kompetensförsörjning på sikt men det leder också till en inre stress i hittills relativt homogena samhällen. För dem som ger sig iväg från sina hem innebär det nytt hopp men också en ständig exil, med allt vad det bär med sig. Det finns knappast någon antydan att flyktingströmmar kommer att minska i världen; nya och fördjupade konflikter, ofta inom länder, och förvärrad förföljelse av olika människogrupper skapar ständigt nya flyktingströmmar och ställer krav inte bara på de grannländer som måste hantera de direkta följderna.

Hur ska vi inom högskolan greppa dessa problem som är så stora att de ständigt överväldigar oss? Som är så stora att vi inte riktigt vågar tänka på dem eller prata om dem med varandra i vardagen? De dyker upp i högtidstal och policydokument men eftersom vi ser dem som så skrämmande och svårlösta, väljer vi att skjuta upp våra egna diskussioner kring dem till lite senare och återvänder till våra vardagsuppgifter och det lilla livet, som är nog så problemfyllt.

Det finns många olika sätt att kategorisera och framställa de globala problemen, inte minst eftersom de i hög grad är sammanvävda med varandra. Ett sätt är att dela upp dem i tre kategorier: ${ }^{67}$

\section{Människans påverkan på naturen är trots allt det minst besvärliga} problemet att prata om och kanske där det är lättast att känna att man kan lämna sitt bidrag till en lösning. Men vi vet samtidigt att vi behöver ändra på hela vårt eget konsumtionsmönster, vår energianvändning och $\mathrm{i}$ slutänden vår livsstil för att åstadkomma en varaktig förändring. Och då blir det inte så enkelt.

2. Gapet mellan fattiga och rika, inom, men också mellan, olika länder och kulturer. Arbetsfördelningen mellan fattiga och rika länder gör att jag för ett par hundralappar kan köpa en välsydd skjorta, som, om den hade tillverkats i samma västland där den bärs, skulle kosta åtminstone flera tusenlappar. I detta gap och i bristen på respekt mellan kulturer

${ }^{67}$ Den här indelningen bygger på den som Jeffrey Sachs gör i sin dystra men hoppingivande skildring i Common Wealth. Economics for a Crowded Planet (2008), s 5-7. 
ligger embryon till förödande väpnade konflikter. Häri ligger också rädslan, som också i sig är en mäktig och farlig fiende. Vi får fortfarande en påminnelse om attacken mot New York 2001 varje gång någon visiteras inför en flygresa. Ekonomin är alltså global, både den delen som omfattar råvaror, tillverkning och konsumtion och den delen som omfattar förväntningar, det vill säga finansmarknaden. Politisk styrning är dock fortfarande i allt väsentligt nationell, byggd på de märkliga gränser för nationalstater som den vindlande historien med dess krig och kolonialism ritat upp.

3. Extrem fattigdom och fortsatt befolkningstillväxt just i de områden som har svårast att klara försörjningen, framförallt under närmast kommande generationerna i Afrika söder om Sahara.

Möjligen skulle ett fjärde och lika svårbemästrat problemområde vara vår egen oförmåga att ta oss an problemen. Vi har inte de globala institutioner vi skulle behöva och framförallt blir vi förlamade och tappar handlingsförmågan vid blotta tanken på problemens storlek. Det gäller att bryta ner problemen i deras beståndsdelar, visa att rimliga lösningar finns och skapa hopp om förändring.

Men vem ska ta sig an dessa problem? Vilka ska formulera de generella, världsomspännande principerna, grundade på de bästa argumenten och mest tillförlitliga fakta? Vilka ska sedan skapa förtroendefulla internationella samarbeten och tillämpa de generella principerna i varje enskilt fall, med deras speciella egenskaper och egenheter? Jag menar att akademin, i betydelsen alla institutioner som bedriver forskning och högre utbildning och alla som deltar eller har deltagit i dessa, är unikt positionerad för att göra en avgörande skillnad i hur världen möter de globala problemen. Till syvende och sist måste folkvalda politiker stifta lagar och avsätta stora resurser för att åstadkomma förändring. Men om det ska vara framgångsrikt måste de göra det på basis av de bästa underlagen; det är förstås här som akademin har sin unika styrka. Därmed kan man tycka att akademin också har ett unikt och stort ansvar att engagera sig. Vi akademiker har mer eller mindre bra betalt av våra samhällen för att ägna hela våra yrkesliv åt att ta reda på hur saker förhåller sig, att lära oss om världen och människorna och sedan kommunicera det vetandet med varandra och, kanske något mindre framgångsrikt, med omvärlden. Idag är det snarare så, hävdar Daniella Tilbury, en drivande akademiker vad gäller hållbarhetsarbete, att de mönster som finns djupt inbäddade i den högre utbildningens kunskapssystem och kunskapssamband bidrar till en ohållbar utveckling. ${ }^{68}$

${ }^{68}$ Daniella Tilbury är professor i hållbarhet vid Univeristy of Gloucestershire, UK, och ordförande i FN:s expertgrupp om utbildning för hållbarhet, bland mycket annat. För argumenten se Tilbury 2012 Higher Education for Sustainability: A Global Overview of Commitment and Progress. http://insight.glos.ac.uk/sustainability/Education/Documents/GUNI\%20HE\%20in\%20the\%20 World\%204\%20HE’s\%20Committment\%20to\%20Sus.pdf (hämtad 2013-02-20) 
Högskolan är, trots dess enorma kunnande och kommunikationsfärdighet, förvånansvärt passiv i att försöka påverka opinion. Vi akademiker skriver sällan om vad vi vet och tycker i lokalpressen eller på nätet och talar sällan i politiska sammanhang eller allmänna debatter. Vi skulle kunna mera aktivt delta i vad som kallats en "skolning av det allmänna medvetandet". ${ }^{69}$ Detta kunde innebära, som jag tolkar det, både ett slags medborgerlig bildning och en medveten påverkan på mediernas framställning av världen. Därför måste högskolorna inte bara anta och examinera studenter utan också spela en starkare offentlig roll. De villkor, incitament och strukturer som behövs för att skapa en sådan kultur bland akademiker, en sådan handlingsförmåga om man vill, kommer att kräva en hel del möda och kanske svåra omprioriteringar för att åstadkomma. Omöjligt borde det inte vara.

\section{Studentinflytande och studentengagemang}

Men studenterna då? Är det inte de som är högskolans största tillgång och starkaste kraft? Det finns en märklig tystnad kring vad studenterna skulle kunna åstadkomma i att påverka dagordningen för framtidens samhälle. I efterdyningarna av 1968 var Sverige tidigt ute med långtgående krav på studentinflytande i högskolornas interna affärer. Studenterna skulle vara representerade i alla lärosätets beslutande och beredande organ, hette det i Högskolelagen fram till 2010. Numera står det att "Studenterna har rätt att vara representerade när beslut fattas eller beredning sker som har betydelse för utbildningen eller studenternas situation." (HL 2 kap 7\$), vilket i och för sig är en helt annan fiskkittel.

Men studentinflytandet är inte vad det var och definitivt inte vad det borde bli, om man på allvar menar att studenter ska bilda sig och skaffa sig handlingsförmågor för att skapa ett bättre liv för sig själva och för andra. Studentkårerna har decimerats till följd av kårobligatoriets avskaffande. Trots det görs ett starkt högskolepolitiskt arbete av engagerade studenter både på lokal och nationell nivå, men de är relativt få - på min egen högskola besvärande få. Dessutom, och detta är möjligen ännu mera besvärande, speglar de frågor studenterna driver företrädesvis en bild av studenten som arbetstagare och konsument. Jag tror inte att huvuddelen av Sveriges studenter bara är intresserade av ett bra jobb med bra lön och det helst så snart som möjligt - men det ser onekligen ut så. Och det kan de knappast klandras för. Förstå mig rätt: jag tycker att studenter ska ha rätt till ekonomisk trygghet vid sjukdom; jag tycker förstås att lärare ska ha en pedagogisk utbildning. Jag stöder livligt att studenter ska "ges" (även om jag föredrar "skaffa sig") "praktiska kunskaper och erfarenheter som kan användas i det framtida arbetslivet". Alla dessa är nämligen huvudpunkter i Sveriges Förenade Studentkårers program $2014 .{ }^{70}$ Men där står ingenting om studenternas

\footnotetext{
${ }^{69}$ Försök till översättning av den både poetiska och talande frasen the schooling of the public mind, använd av Henry Giroux om mediernas roll i samhället (Giroux 1974, s 7).

${ }^{70} \mathrm{http} / / / \mathrm{www} . s f s . s e / \mathrm{i}$-fokus/kvalitet 2014-04-01
} 
engagemang i de stora samhällsfrågorna. Det är möjligt att många tycker att sådana sköts bäst av de politiska partierna eller, som tycks vara betydligt vanligare bland ungdomar idag, genom nätverk och enfrågesammanslutningar på Internet.

I slutet av sitt liv ser historikern Tony Judt tillbaka på de generationer av studenter han mött under 40 år, främst i England men också i USA från början av 1970-talet och framåt. År 1971 ville alla studenter bli betraktade som någon form av marxist, skriver han; år 2000 fanns knappt en grundstudent som visste vad ordet marxist betydde, än mindre varför det en gång i tiden var så tilltalande. Han kallar 90-talet och 00-talet "de själviska årtiondena", då unga människors främsta ambition var att bli rik och då Business Schools växte sig starka. Men, fortsätter Judt, kan de verkligen klandras som själviska? ”Då de från alla håll fick försäkringar om att radikala förändring tillhörde det förgångna, såg de runtom sig inga exempel som var värda att följa, inga diskussioner att kasta sig in i och inga mål att sträva emot. Om meningen med livet, så som det levs av alla inom synhåll, är att vara framgångsrik i affärer så blir det till ett "standardmål" för alla utom de mest självständiga ungdomarna. Det var Tolstoj som skrev: '... det finns inga livsvillkor som man inte kan anpassa sig till, särskilt om man ser att de accepteras av hela ens omgivning."' ${ }^{1}$

Sinziana Ravini, lektor i estetik vid Sorbonne och redaktör för konsttidskriften Paletten, är uppfriskande rättfram bland alla uppgivna humanister i en essäsamling om humanioras ställning: "Svensk humanioras största och kanske mest iögonfallande problem är universitetslärarnas bristande studentengagemang"72, skriver hon och fortsätter: "Studenterna har blivit humanioras blinda fläckar. Ingenstans hörs deras röster, deras framtidsdrömmar." Och inte bara humaniorastudenterna, skulle man kunna tillägga. Själva är studenterna för upptagna av konkurrens om platser och betyg och om sina framtida yrken för att hinna med, och lärarna faller alltför villigt in i kursplanernas utstakade och välfyllda väg. De som valt humaniora har åtminstone tagit ett modigt avsteg från den raka yrkesvägen. Det ligger ett stort ansvar hos dessa unga vuxna att själva kräva mera än ren och kortsiktig yrkesförberedelse. Men jag tror också att det är vi som är anställda på högskolorna som är bäst positionerade för att driva in en kil i samförståndet som vuxit fram om den smala och effektiva utbildningsvägen. Om vi vågar utmana vårt eget system har vi möjligheten att driva fram en utveckling hos studenterna genom att kräva att de tar ansvar för sin egen bildning och för ett engagemang i samhällsfrågorna. Vi behöver förvänta oss mer än ifyllda tentor och inlämnade rapporter. Och om vi måste poängsätta och betygsätta även sådana insatser för att de ska bli tagna på allvar så, säger jag motvilligt, låt det ske.

Vid Uppsala universitet och SLU finns sedan närmare två decennier en verksamhet som drivs av studenternas egna krav och kraft. CEMUS, Centre for Environment and Development Studies, heter verksamheten. Varje år möter

\footnotetext{
${ }^{71}$ Judt 2012, s 209f. Tolstoj-citatet är från Anna Karenina.

${ }^{72}$ Ravini 2012, s 251.
} 
omkring 600 studenter de stora utmaningarna i ett tjugotal kurser som de anordnar själva. Kurserna behandlar de frågor som de själva ser som väsentliga men som de inte mött i tillräckligt hög grad under sina programutbildningar till ingenjör, lärare eller något annat - global ekonomi, världens miljöhistoria, människan och naturen. Universitetet anställer studenterna som amanuenser och ger dem ansvaret - och återkommande stöd och utbildning - för att själva utforma och driva flervetenskapliga kurser som oftast handlar om de globala utmaningarna i större perspektiv. Studenterna bjuder in gästföreläsare från universitetets olika fakultet men även från andra håll, och håller ihop kursen genom seminariediskussioner. Det sker oftast utanför programutbildningarnas hägn och fungerar också som testbädd för nya pedagogiska grepp med studentaktiva former som grund. Det är ett föredöme som manar till efterföljd.

På Sorbonne, berättar Sinziana Ravini, anordnar studenter på torsdagarna Les Jeudis de la Sorbonne, där de inbjuder personligheter från omvärlden till samtal och "studenterna får chansen att både berömma, kritisera och i vissa fall inleda samarbeten med personer från samhällets mest skilda håll”. Evenemangen är obligatoriska, de betygsätts, och populära bland studenterna. När vi vid Högskolan Dalarna under några terminer vid millennieskiftet frilade hela högskolan från undervisning på onsdagseftermiddagarna och erbjöd flervetenskapliga och tematiska kurser för studenter och lärare i form av vad vi kallade Onsdagskollokviet, borde vi kanske varit ännu modigare och krävt att studenterna själva anordnat dem. Ravini avrundar sitt resonemang genom att slå fast att "ett universitet kan aldrig bli en aktiv del i ett demokratiskt samhälle om det inte hjälper studenterna med det mest avgörande övergångsstället i ett intellektuellt äventyr. Passagen från den ack så viktiga frågan 'vem är jag?' till den allra viktigaste av dem alla: 'Vilket samhälle vill jag leva i?' Men för detta måste universitetet börja betrakta studenter som aktiva politiska subjekt som är fullt kapabla att påverka sin framtid här och nu."73

Vilket påminner allt en hel del om ett resonemang jag förde under en tidigare princip kring seminariet som det jämlika tilltalets arena. Med hjälp av Jacques Rancière hävdade jag att vi lärare systematiskt underkänner våra studenters intelligens och förmåga och att ett jämlikt tilltal, inte bara låtsat, mellan lärare och student, utgör en grund för en bildningsprocess som kan ge aktiva och engagerade medborgare. ${ }^{74}$

\section{Om global uppvärmning och tvivlets makt}

Forskningen och vetenskapssamhället har i många sammanhang stått upp för det man vet, skrivit upprop och deltagit i debatter, antagit uttalanden och försökt påverkat politiker. Trots allt är det först nu 2014 som världens media och

\footnotetext{
73 Ibid s 255.

${ }^{74}$ Se Princip 2 ovan och Rancière 1991.
} 
därmed dess befolkning börjar vara överens om att det verkligen finns en global uppvärmning, orsakad av människans aktivitet, och att något borde göras. Då har det gått över hundra år efter Svante Arrhenius skrev om sambandet mellan växthusgasen kolsyra och global uppvärmning. Visserligen trodde Arrhenius att det skulle i princip vara gynnsamt för världen eftersom det skulle ge större skördar för att mätta en växande befolkning; ${ }^{75}$ det skulle dröja in på 1960-talet innan den samlade vetenskapen började anse att det fanns en påtaglig risk för klimatpåverkan skapad av människans användning av fossila bränslen. Men även om USA:s dåvarande president Lyndon Johnson nämnde problemet i ett tal till kongressen redan 1965, dröjde det ännu flera decennier innan det riktigt nådde den politiska agendan - och det var då som en allmän debatt uppstod om huruvida det verkligen finns en global uppvärmning och om den i så fall beror på människans användning av fossila bränslen.

Hur kan det komma sig att det har tagit så lång tid för världen att nå någon form av konsensus omkring vad som hänt och vad som fortfarande pågår när det gäller människans påverkan på klimatet? $\mathrm{Nu}$ är ju världen förstås fortfarande skrämmande långt från att med förenade krafter göra någonting åt det, men historien hittills är ändå lärorik. Den rymmer nämligen ett antal varnande exempel på interaktionen mellan vetenskap, marknad, medier och samhälle. Den ger också varnande exempel på hur det kan gå när akademin, eller åtminstone några högljudda företrädare för den, engagerar sig, men resultatet inte blir att man närmar sig en lösning, utan precis tvärtom.

Det är en lång och komplex historia som det ändå går att dra några relativt enkla slutsatser från. Hela förloppet från mitten av 60-talet och fram till idag när det gäller allmänhetens och politikernas insikt att det faktiskt pågår en global uppvärmning, att den skapats av människan och att den kommer att öka om vi inte gör någonting, berättas från det amerikanska perspektivet av Naomi Noreskes och Erik Conway i deras Merchants of Doubt - How a handful of scientists obscured the truth on issues from tobacco smoke to global warming från 2010. Det amerikanska perspektivet är naturligtvis avgörande för hur hela världen uppfattar frågan, inte bara genom de stora resurser och enorma prestige som det amerikanska vetenskapssamfundet åtnjuter, utan också tack vare det världsövergripande genomslaget av de amerikanska medierna och den amerikanska kulturen. Redan bokens titel anger tesen. Det har nämligen funnits ett antal respekterade och inflytelserika forskare som genom åren sått tvivel kring vad resten av vetenskapssamhället har varit överens om.

Deras första exempel gäller rökning. I över 30 år lyckades tobaksindustrin hålla stånd mot kända, bevisbara och av vetenskapssamhället noga granskade fakta. Kända forskare svor under ed att det inte var bortom rimligt tvivel att tobaksrök orsakade specifika sjukdomar. Mäktiga ekonomiska intressen stod på spel och vi som då var nikotinberoende sög i oss alla tecken på tvivel som åtminstone kunde skjuta på den dagen vi var tvungna att göra uppror mot

\footnotetext{
${ }^{75}$ Se Svante Arrhenius Världarnas utveckling 1906, s $60 \mathrm{ff}$.
} 
missbruket och sluta röka. De allmänna slutsatser som Oreskes och Conway drar när det gäller allmänheten och vetenskapliga fakta är främst tre: För det första finns många som har svårt att förstå vad en orsak innebär. Om man säger att rökning orsakar cancer så innebär det inte att alla som röker får cancer; det innebär att många fler rökare får cancer än icke-rökare. Men man avvisar gärna en sådan statistisk sanning med hänvisning till egna eller andras faktiska erfarenheter: farfar började röka när han var tretton och han har inte fătt cancer. För det andra så är ju hela vetenskapens livsluft just tvivel. Grunden i ett vetenskapligt förhållningssätt är att utsätta vedertagna sanningar för ständiga angrepp och tester, att pröva nya hypoteser; vad tobaksindustrin kom underfund med var att man kunde använda vetenskapens systematiska tvivel för att i mediernas och allmänhetens ögon underminera vedertagen och rigoröst prövad vetenskaplig sanning. För när allt kommer omkring så är inte en vetenskaplig sanning mera än vad vetenskapssamhället för närvarande har funnit är den bästa sanningen. Men detta är svårt för många att acceptera. När vi läser en tidningsartikel eller ser en TV-debatt där två versioner står emot varandra, vill vi gärna låta båda sidor höras. Då finns en överhängande risk att många läsare eller tittare drar slutsatsen att det ändå finns ett rimligt mått av tvivel - trots att den ena kontrahenten har hela den samlade vetenskapen på sin sida och den andra bara sina egna, kanske ofta anekdotiska, påståenden. Det finns inte helt säkra bevis, tänker vi. Med just de orden som motto kunde man så tvivel om allt från tobakens skadeverkningar till global uppvärmning, slå undan stämningsansökningar i rätten och skjuta upp överenskommelser om koldioxidutsläpp i decennier. Hur man gjorde detta och vilka som ledde tvivlet kartlägger Oreskes och Conway i detalj och det finns knappast någon anledning att ifrågasätta deras historieskrivning.

Det är inte heller bara politiker och allmänhet som sitter i en jury som låter sådant tvivel, som egentligen inte är något tvivel i ordets vardagliga mening, bli avgörande. Det är också de mäktiga medierna och deras journalister. Journalister är tränade för att ge en balanserad bild, att låta båda sidor komma till tals. Inte heller de kan alltid förstå eller bedöma skillnaden mellan vedertagen vetenskaplig fakta och ogrundat tvivel. Inte minst om de som uttalar sig är kända forskare med långa meritlistor bakom sig, låter man dem komma till tals i tidningen eller debattprogrammet. Det passar ju så väl in i mediernas grundläggande format för faktaunderhållning, det vill säga ordduellen, helst med en uppretad och högljudd publik, som är en nödvändig förutsättning för att hålla uppe tittarsiffrorna. Det är inte alls säkert att man kontrollerar vilken legitimitet en viss expert har att uttala sig om just den frågan som är under debatt. Andra faktorer är förstås viktigare när det gäller plocka ut kontrahenterna, även om journalisterna är seriösa, vilket de oftast är. Och vi måste trots allt i någon mån lita på de experter vi får möta i medierna. Vi kan inte utföra forskningen själva. Vi måste lita på forskarna att de har gjort sitt jobb och kontrollerat sina resultat på det mest rigorösa sättet de kan. Men då måste inte minst journalisterna axla ett tungt ansvar, att kunna skilja mellan å ena sidan 
goda forskare som följer det vetenskapliga sanningssökandets regler och finner sig i dess välgrundade resultat och å andra sidan forskare med ett särintresse av något slag att främja genom sina uttalanden.

I de fall som jag refererat till i Oreskes och Conways framställning finns för övrigt en intressant uppsättning särintressen, som i mycket speglar de motiv som kan få även ledare för världens största demokratier att handla galet, eller, som i fallet med global uppvärmning, att inte handla alls. Det är nämligen så, enligt författarna, att flera av de inflytelserika forskarna som ledde tvivelsådden om tobaksrök och ozonhålet hade sin bakgrund i USA:s kärnvapenprogram under kalla kriget och senare i Ronald Reagans Star Wars-initiativ på 80-talet. Som sådana var de uttalade antikommunister och såg kommunisthot i varje ingrepp mot en helt oreglerad marknad. Alla som värnade miljön var misstänkta. De kunde vara "vattenmeloner": gröna på utsidan men röda inuti. ${ }^{76}$ Eftersom den globala uppvärmningen beror på effekterna av en i stort sett oreglerad användning av fossila bränslen på en fri marknad, måste varje försök att komma till rätta med miljöskadorna innebära någon form av statlig inblandning i den fria marknaden. Vilket i sin tur innebar ytterligare ett steg mot socialism och kommunism. Milton Friedman, ekonomipristagare och ekonomisk ledsagare till både Reagan och Thatcher på 80-talet, uttrycker farhågorna tydligt i sin Capitalism and Freedom när han skriver att "ekonomisk frihet är lika viktig som medborgerlig frihet, eftersom om man förlorar den ena friheten är det bara en tidsfråga innan den andra också går förlorad. Därför måste man försvara den fria marknaden med samma kraft och vaksamhet som åsiktsfrihet, religionsfrihet och mötesfrihet." ${ }^{\prime 77}$ Det var liknande åsikter i USA - och för all del på annat håll också - som hindrade genomförandet av åtgärder i enlighet med Rio-överenskommelsen och Kyoto-protokollet. En global överenskommelse minskar nationers och individers frihet, ansåg den fria marknadens inflytelserika apostlar, både i USA och på annat håll. Åtgärder för att öka hållbarhet minskar ekonomisk tillväxt och fortsatt tillväxt är oundgänglig för människans frihet och välfärd, hette det - och heter.

Men om den stora majoriteten inom akademin ändå visste att de som sådde tvivel var bluffmakare, i storfinansens och marknadsfundamentalismens sold, vad hindrade dem från att uttala sig högre, tydligare, oftare? Under nästföljande princip ger jag en bild av splittringen mellan naturvetenskapen och humanvetenskapen, dess ursprung och konsekvenser. Jag tror nämligen att denna splittring utgör en del av problemet, möjligen mindre i USA än i Sverige och andra europeiska länder, där naturvetare ännu hellre retirerar till mark där de kan känna sig säker, utan att ge sig ut i det som de uppfattar som politik, med de konsekvenser det kan få för framtida anslag. Humanvetare, å andra sidan, har sällan ett tillräckligt naturvetenskapligt självförtroende för att de överhuvudtaget ska vilja läsa in sig $i$, än mindre uttala sig om, samhällsproblem med

76 Oreskes \& Conway 2010 s 248.

77 Friedman 2002 (1962), s $7 f$. 
naturvetenskapliga eller tekniska förtecken. Forskare i allmänhet är också obenägna att uttala sig offentligt om sådant de inte känner sig helt trygga med. De är uppfostrade så. Och populärvetenskap är inget som de förväntas ägna sig åt; den ger inget status eller anslag i en värld där status och anslag betyder allt. Dessutom ger Oreskes och Conway ett flertal exempel på forskare som blivit förföljda, till och med ruinerade, för att de gått till angrepp mot de mäktiga krämare som handlar med tvivel. ${ }^{78}$ Sådant är det fullt förståeligt om man vill undvika.

Resonemanget kring varför det har tagit så lång tid för världen att erkänna den globala uppvärmningen väcker också frågor om utbildningsnivåer. Det är inte alldeles enkelt att kunna skilja vetenskapligt belagda förhållanden från lösa tyckanden om man inte på allvar och i praktiken själv sysslat med sådana frågor. Och om man till fullo ska kunna spela sin roll som medborgare i ett demokratiskt samhälle räcker inte den osjälvständiga utbildningsgången som grund- och gymnasieskola kan ge. Den högre utbildningens särmärke är det självständiga, kritiska ifrågasättandet på goda grunder. Den förmågan behöver alla medborgare ha.

\section{Risksamhället - vår rädsla skapar vår värld}

Den globala uppvärmningen är ett stort och överhängande hot mot vårt globala samhälle. Om det kan det inte råda någon tvekan. Samtidigt är det viktigt, för att kunna anlägga ett rimligt och rationellt perspektiv både på det hotet och på andra hot, att förstå hur vi, åtminstone i västvärlden, iscensätter och förstår risker och hot över huvud taget. Hela vårt västerländska samhälle är idag upptaget av att identifiera och försöka avvärja risker. Medierna säljer aldrig så bra som när de har en ny risk att berätta om, gärna en hälsorisk av något slag. Hur liten eller avlägsen risken än är, vill vi veta om den och hur vi bäst skyddar oss och våra familjer mot den, vare sig det gäller cancerframkallande ämnen i maten eller alkoholens, sockrets eller fettets fördärvliga hälsopåverkan. Risker finns också runtom oss i form av våldsverkare, både i lokalsamhället och i det globala samhället, där den internationella terrorismen når sina mål effektivare genom den rädsla den skapar än genom de faktiska vålds- och terrorgärningarna. Och det är förstås just det som terrorism betyder - latinets terrere betyder att skrämmas. Vi bygger upp våra samhällen för att varna för och mota riskerna, sådant som skulle kunna hända, oavsett hur stor eller liten sannolikheten är. Varje produkt vi köper beledsagas av en varning, för explosioner, kvävning eller nötter. Var och varannan lyktstolpe, åtminstone i UK, har en kamera för att skydda oss från kriminella handlingar; vi accepterar den ständiga övervakningen och intrånget i vår frihet för att vi tycker det är viktigare att beskyddas från risker.

${ }^{78}$ Se till exempel Oreskes \& Conway s 1-5 om Ben Santer, en av världens mest framstående miljöforskare, och hans kamp att vinna upprättelse. Även ibid s 164-165. 
Vi låter oss kroppsvisiteras inför varje flygresa därför att vi premierar trygghet och en minskad risk.

Det var den tyska sociologen Ulrich Beck som förde fram begreppet "risksamhället" under 1980-talet och skrev standardverket i ämnet, The Risk Society. Towards a New Modernity. Grunden i hans resonemang är att medan det i det förmoderna samhället, det vill säga fram till ungefär 1600-talet, lurade långt flera risker för hälsan och säkerheten än det gör idag, är vi nu långt mera medvetna om riskerna. Bland de allra viktigaste anledningarna till detta var den växande övertygelsen i det moderna samhället, jämfört med det förmoderna, att vi faktiskt kan påverka risker, utfall och resultat. Vad som händer i livet är inte resultatet av en allsmäktig guds förutbestämda plan för oss, eller av ett möjligen orättmätigt men trots allt utstakat öde. En växande protestantisk tro som satte människan som ansvarig för sin egen lycka, tillsammans med de rationella orsakskedjorna som började upptäckas av den naturvetenskapliga revolutionens vetenskapsmän, gjorde att vi började se risker, helt enkelt därför att vi kunde påverka dem. Vi kunde till och med börja mäta riskerna, tack vare den sannolikhetskalkyl som Fermat och Pascal utvecklade under mitten av 1600-talet.

Nu insåg vi att det var våra beslut som avgjorde vår framtid; det var vi själva som hade ansvaret. Och då kunde vi minska osäkerheten och öka tryggheten genom att dela på riskerna med andra, företrädesvis genom olika typer av försäkringar. Ömsesidiga försäkringar för att lindra risktagandet hade börjat utvecklas tidigare av den snabbt växande globala handeln. Att utrusta skepp för årslånga turer till orienten var ett dyrt och riskfyllt företag. Att dela på risken med andra var så gott som en förutsättning för en så stor investering. Ända sedan dess tycks det allmänna riskmedvetandet ha fortsatt växa, och med det också, förklarligt nog, försäkringsväsendet. Andra faktorer vägde in i den utvecklingen också, i och för sig: i Sverige betydde ett starkare privat ägande genom skiftesreformerna under det tidiga 1800-talet att individen drabbades hårdare av brand och behövde försäkra sig, alltså sprida risken på ett annat sätt än genom gemensamt ägande. Historiker menar att detta var en viktig faktor för den allmänna ekonomiska tillväxten och möjligheten för Sveriges industri att börja växa: eftersom man var ensam ägare till sin fastighet och hade försäkrat den mot risker, främst brandrisken, som också ökat genom inflyttningen till städerna, kunde man belåna den och investera kapitalet i industriell tillverkning eller så lyder resonemanget $\mathrm{i}$ starkt förenklad version. ${ }^{79}$ Tillsammans med livförsäkringar, som vädjade till familjefaderns ansvar för att avvärja den ekonomiska katastrofen som hans egen död skulle innebära, gjorde brandförsäkringar att försäkringsväsendet kunde ta riktig fart under 1800-talet, både som ömsesidiga bolag och som vinstdrivna aktiebolag. Försäkringsbolag utgör

${ }^{79}$ För en sammanfattning av forskningsresultat kring detta se Lars-Fredrik Anderssons rapport från projektet Det svenska försäkringsväsendets historia 1850-1939. http://www.rj.se/Global/ Slutredovisningar/2006/Lars_Fredrik_Andersson_sv.pdf 
sedan dess en viktig bas i finanssystemet och är fortfarande en egen tillväxtsektor där vi numera försäkrar inte bara liv och hem utan även hund och katt, cykel och kylskåp - de sistnämnda för att avvärja den ekonomiska risken en hemförsäkring kan innebära genom dess självrisk.

På sådana sätt, bland flera andra, har vår inställning till risker bidragit till att utforma våra samhällen, inte minst därför att med möjligheten att påverka risker följer ansvar och skuld. Beck hävdar att hela utvecklingen av våra moderna samhällsinstitutioner under 1900- och 2000-talen kan förstås som den konfliktpräglade utvecklingen av ett regelsystem för att svara upp mot osäkerheter och risker. ${ }^{80}$ Alltså är det främst för att fatta beslut under reglerade former och fördela ansvar och skuld, förebygga och täcka risker, som vi har utvecklat våra statliga och kommunala beslutsorgan och myndigheter, våra banker och försäkringsbolag. Och under dessa århundraden har vi i ökande grad vänt oss till experter, ofta forskare, för att bättre förstå och förebygga riskerna. Tilltron till de naturvetenskapliga forskarna och deras resultat har varit kompakt och orubbad, och egentligen bara vuxit, trots massförstörelsevapen och miljöförstöring. Det som har hänt i vår tid är, menar Beck, att världen inte längre kan styra de faror och risker som moderniteten, det vill säga industrisamhället, utsätter oss för. Och det beror inte på vårt samhälles brister och misslyckanden utan på dess framgångar.

Våra liv har blivit längre och tryggare i de allra flesta delarna av världen. Förmågan att effektivisera matproduktionen har fört med sig hoten som skapats av övergödning; den industriella tillväxten som varit grunden för vårt välstånd har fört med sig klimatförändringar som troligen kommer att hårdast drabba dem som inte fått så stor del av välståndsökningen, bland annat i Östafrika. Jakten på alltmer energi har inte bara bidragit till klimathoten utan även till hoten från kärnkraften. Utan flygplanens välsignelse för globala kommunikationer och transporter, inga 9/11-hot. Utan demokratiseringens och upplysningens Internet, ingen global övervakning och förföljelse ända in i människans mest privata sfärer. Och så vidare - den moderna människans framgångar bär med sig de överhängande hoten.

En risk som är något mera komplicerad att förklara är risken för arbetslöshet och inte minst den massarbetslöshet som numera hotar inte bara under lågkonjunkturer utan som tycks bli en permanent del av högeffektiva industriella samhällen. Det är i det moderna samhället som arbete och flit har blivit de högsta dygderna, uppburna i lika hög grad av religioner, folkrörelser, företagsledare och politiker i alla läger. Och det är förstås hårt arbete och flit som lett till det samhälleliga välstånd som vi njuter av idag. Därmed har också det moderna samhället skapat vårt beroende av ett ordnat jobb, gärna i form av

\footnotetext{
80 "The political history of the institutions of the developing modern society during the nineteenth and twentieth centuries can be understood as the conflict-ridden evolution of a system of rules for responding to industrial uncertainties and risks, hence those produced by decisions." Beck 2009, s 7.
} 
en trygg anställning, och gjort det till en omistlig del av vår sociala identitet och status, förutom att det ger pengar inte bara till livets nödtorft utan också möjlighet att delta i konsumtionssamhällets tillfredsställelser. Arbetet i sig ger också naturligtvis en viktig individuell tillfredställelse för de allra flesta av oss. Men så har det inte alltid varit. I förhistoriska samhällen arbetade man bara så länge man behövde för att få ihop till livets nödtorft. I en del förmoderna samhällen, t.ex. den antika grekiska, som annars under två årtusenden utgjort den främsta förebilden för västerländsk civilisation, har arbete betraktats som förnedrande, något som de lägsta klasserna, de som inte ens räknades som medborgare, var tvungna att syssla med. Det är också det moderna samhället som genom fortsatt, oförtruten mekanisering och rationalisering minskat på behovet av arbetskraft, åtminstone i de delar av samhällsekonomin som syftar till att skapa överskott för ägarna. I synnerhet har behovet av de mindre kvalificerade och mera fysiska arbeten minskat. I andra delar av samhällsekonomin, byråkratin till exempel, verkar ofta målet att rationalisera skapa mer arbete, något jag försöker förstå under en annan princip. ${ }^{81}$ I vården, omsorgen, skolan däremot är behovet av mänsklig arbetskraft oändligt, begränsat bara av vår vilja att satsa offentliga medel.

Man skulle kunna tänka sig att vi kunde dra ner på arbetstiden och skippa tävlingen om vem som hinner och orkar jobba mest. I stället jobba mindre, till förmån för familj och fritidsintressen och betrakta det fria livet, utan mer tvingande lönearbete än nödvändigt, åter som norm. Och det finns naturligtvis någon politisk inriktning och en och annan kolumnist som pläderar för en sådan utveckling, medan tidsandan och de flesta politiker tycks gå i motsatt riktning. Den tidigare strävan att minska arbetsveckan och öka semestertiden, som åtföljt välfärdssamhällets utveckling alltsedan det tidiga 1900-talets samhällsreformer, verkar de senaste decennierna både avstannat och gått över i sin motsats. Både i Sverige och, till exempel i Frankrike, där 35-timmarsveckan infördes 2000. I praktiken arbetar vi i västvärlden allt längre varje vecka och allt längre i våra liv. Det moderna, västerländska samhället har alltså genom sin framgång i att genom hårt arbete förbättra våra liv och samhällen skapat arbetslöshet, både som hot och destruktiv verklighet, säger Ulrich Beck. ${ }^{82}$ Han pekar därmed på en typ av paradox som verkar vara typisk för samhällsutvecklingen, en motsägelsefull verklighet som inte är alldeles enkel att förstå. "Motsatsernas galna pardans" kallar den slovenska filosofen och kulturkritikern Slavoj Zizek det för, i en träffande fras. Den galna pardansen illustrerar han just med "den märkliga samexistensen av intensivt lönearbete med hotet om arbetslöshet; ju mer intensivt de anställda arbetar, ju mera allmänt blir hotet om arbetslöshet." ${ }^{33}$

81 Se Princip 14 nedan.

82 Se Beck 2009, s 214 ff.

83 "The mad dance of opposites /.../ the weird coexistence of intense employment with the threat of unemployment: the more intensely those who are employed work, the more generalized is the threat of unemployment." Zizek 2014, s 21 
Och att verkligheten är motsägelsefull och svårförståelig skapar också en risk för förenkling som vilseleder varje försök att påverka den fortsatta utvecklingen.

Sedan är det frågan om vilka förenklingar man väljer att presentera för världen, hur man formulerar frågorna och hoten, helt enkelt hur man iscensätter risk. Här har förstås de företrädesvis fortfarande nationella medierna en avgörande roll. Om man väljer att lyfta fram omtvistade resultat om global uppvärmning och skildra en "debatt" mellan experter kommer man knappast att påverka en opinion för omfattande uppoffringar, uppoffringar som måste ske idag för att komma undan oklara effekter i framtiden. Om man däremot visar ett samhälle vars hopp är satt till fortsatt tillväxt, att global uppvärmning kommer att orsaka marknadskollaps och en ekonomisk depression värre än världen någonsin har skådat, blir det betydligt lättare för politiker att plötsligt upptäcka en ny iver för att rädda planeten och dess artrikedom. ${ }^{84}$ Hur risker iscensätts när det gäller global terrorism har förstås redan haft betydande konsekvenser, till exempel genom kriget i Irak.

Hoten är alltså inte längre bara individuella, lokala eller ens nationella. De är i allt högre grad globala. Klimathoten, terrorismen, finanskriserna som bär med sig ekonomisk depression och massarbetslöshet - ingen av dem går att styra eller avvärja inom rikets gränser. Det finns tre utmärkande drag hos de globala riskerna, säger Beck: de är, för att efter moget övervägande använda tre ord som mitt Word-program ilsket underkänner med rött, delokaliserade, oberäkningsbara, och okompenserbara. De är delokaliserade därför att de sprids över nationsgränser och kontinenter, som klimathoten; därför att den tidsperiod som de påverkar världen är obegränsad, som klimathoten men också, till exempel, kärnavfallet; och för det tredje därför att både deras upphov och deras effekter består av så långa och komplexa händelsekedjor att de inte går att beskriva med sådan exakthet att de kan påverkas. De är oberäkningsbara av delvis samma anledning, men också därför att de helt enkelt inte ännu har hänt. Man kan därför inte heller beräkna effekterna. De är okompenserbara därför att de inte går att ersätta med pengar eller något annat. Ett hus som brinner ner kan man ersätta med pengar för att bygga upp ett nytt. En planet som får förändrade livsvillkor genom klimatförändringar går inte att kompensera för, vare sig med pengar eller på något annat sätt. ${ }^{85}$

Men om riskerna och hoten är globala, hur kommer det sig? Vad är egentligen globaliseringen som alla samhällsanalytiker ständigt hänvisar till? Är det

${ }^{84}$ Jag tänker på The Stern Review on the Economic Impact of Climate Change från 2006 som hade en betydande effekt på hur brittiska medier och inte minst brittiska politiker såg på arbetet med att minska koloxidutsläppen.

${ }^{85}$ Becks resonemang är både rikare och betydligt mera komplext än jag kan redovisa för här. Det återfinns i kapitlet "The Cosmopolitan Moment of World Risk Society or: Enforced Enlightenment" (Beck 2009, s 47-66), där det i begreppet 'påtvingad upplysning' (enforced enlightenment) finns en optimistisk tanke om att världens stater till slut blir helt enkelt tvingade att samarbeta för att överleva. 
en ny värld, som under kort tid skapats av snabba kommunikationer, eller är den förklaringen ännu en $i$ en lång rad av de tydliga svartvita kontraster som vi så ofta konstruerar för att förstå världen - förr var den si, nu är den så - men som i sin förmodade enkelhet och tydlighet ofelbart leder oss vilse?

\section{Globaliseringen}

Globaliseringen och den utveckling den för med sig har varit i centrum för politikers, företagares, finansexperters och även akademikers intresse i över två decennier nu. En tidig definition stod den brittiska sociologen Anthony Giddens för: "Globaliseringen kan således definieras som en ökning av världsövergripande samhälleliga relationer som länkar ihop avlägsna orter på ett sådant sätt att lokala skeenden formas av händelser som äger rum långt borta, och tvärtom." ${ }^{86}$ Hos tongivande sociologer som Giddens och inte minst Manuel Castells har fenomenet först och främst kommit att avse snabba flöden av kapital och investeringar över vad som för finansvärldens beslutsfattare och operatörer är en värld helt utan gränser; dessa flöden styr produktion och handel. Globaliseringen sätts också i samband med migration, migration som delvis hänger ihop med dessa produktionsflöden men också, och inte minst, med långväga flyktingströmmar. Dessa skapas av en svårgenomtränglig orsakskedja, med rötter inte bara i klimatmässiga och geopolitiska händelser utan också $\mathrm{i}$ relationer mellan etniska och sociala grupperingar. Ett tredje område som brukar diskuteras är den globala överföringen av och tillgången till kunskap. För min egen del tror jag inte man kan därutöver överbetona betydelsen av en global och momentan mediebevakning och distribution. Vad betyder det att hela världen, i princip om inte i praktiken, har tillgång till samma nyhetsförmedling samtidigt? Både Fox News och Al Jazeera. Vad betyder det att det är samma tecknade barnprogram som når allt större barngrupper i alltfler länder? Och vad kommer det att spela för roll att två krigsspel på nätet, Dota 2 och Counter-Strike, den dagen som jag skriver detta, har omkring en miljon samtida spelare - alltså, som spelar aktivt just i detta ögonblick - fördelade över hela jordklotet, en stor majoritet av dem unga män? ${ }^{87}$ Vad betyder det att alla de stora städerna i världen har i stort sett samma butiker och märken på sina dyrare shoppingstråk och vad betyder det att McDonalds har 33000 snabbmatställen i 121 länder ${ }^{88}$ som Wikipedia uppger dagligen betjänar 68 miljoner kunder? ${ }^{89}$ Och vad betyder det, för övrigt, att Wikipedia så totalt dominerar insamlingen

\footnotetext{
86 "Globalization can thus be defined as the intensification of worldwide social relations which link distant localities in such a way that local happenings are shaped by events occurring many miles away and vice versa" Giddens 1991, s 64.

${ }^{87} \mathrm{http} / / /$ store.steampowered.com/stats/?snr=1_steam_4_110 2014-05-15

${ }^{88} \mathrm{http}: / /$ en.wikipedia.org/wiki/List_of_countries_with_McDonald's_restaurants 2014-05-15

${ }^{89} \mathrm{http} / / /$ en.wikipedia.org/wiki/McDonald's 2014-05-15
} 
och distributionen av information till hela världen på 238 språk med en halv miljard unika besökare under en månad?90

Hos Giddens och Castells finns en betydande pessimism när det gäller effekterna av globaliseringen på en ökande ojämlikhet och instabilitet $i$ världen. Andra ${ }^{91}$ har velat se den moderna globaliseringen bara som den senaste fasen $i$ en lång utveckling av världsomspännande handel och kapitalinvesteringar som egentligen pågått sedan upptäcktsresandenas tid. De hävdar att det var på 1880talet som den verkliga revolutionen $i$ kommunikationerna inträffade, nämligen med telegrafen. Men även om olika former av globalisering har uppträtt sedan antiken och inte minst under de västereuropeiska koloniernas storhetstid, är det framförallt de digitala kommunikationerna och dataöverföringen som öppnat för den världsomspännande ekonomin som griper in och styr livsvillkoren för varenda människa på jordklotet - något mindre möjligen i Nordkorea.

Om man tar den globala migrationen som ett exempel, kan den illustrera komplexiteten i orsakskedjor bakom avgörande händelser i en globaliserad värld. Nu är i och för sig global migration knappast något nytt fenomen; folkgrupper har vandrat över världen sedan urminnes tider och under senare århundraden behöver man bara peka på invandringen till Nordamerika. Men i en globaliserad värld sker förflyttningar snabbt och i stor skala. Mer än två miljoner har hittills flytt från sitt hemland Syrien, de flesta till grannländerna, men flera tiotusentals till länder längre bort, däribland Sverige. Flyktingströmmar, inte bara från Syrien förstås, utan också från andra konfliktdrabbade områden som Eritrea och Somalia, påverkar hittills relativt homogena svenska samhällen på ett mycket märkbart sätt och skapar nya möjligheter och problem i kommuner som tar emot hundratals flyktingar årligen, som Eskilstuna, Flen eller Avesta. Men den i särklass största ursprungsland för flyktingar som söker asyl i Sverige är, just nu när jag skriver, Syrien. Omkring 20000 syrier verkar det komma till Sverige under 2014. Sedan hösten 2013 ger Sverige i princip permanenta uppehållstillstånd till alla asylsökanden från Syrien. En utväg i nödläge, även om det är möjligt bara för en liten andel av den stora flyktingströmmen att företa en sådan resa. Men just för att flyktingströmmen från Syrien är så aktuell i Sverige kan det finnas skäl att kort illustrera de globala orsakssammanhangen med hjälp av den. Här lånar jag ett resonemang från en föreläsning av samma Jeffrey Sachs, som jag hänvisat till tidigare. ${ }^{92}$

Sachs visar nämligen hur bakgrunden till att tusentals människor flyr från sitt hemland i Syrien finns i fyra var för sig komplexa subsystem och de ännu mera komplexa kopplingarna mellan dem. När det gäller det geofysiska subsystemet var det framförallt torkan som spelade in. Syrien, liksom flera grannländer, led

${ }^{90}$ http://en.wikipedia.org/wiki/Wikipedia 2014-05-15, siffran avser februari 2014.

${ }^{91}$ Se t ex Hirst and Thompson Globalisation in Question (1996).

92 Föreläsningen vid Columbia University, New York, heter The Path to Sustainable Development (25 Feb 2014) och återfinns på http://www.earthinstitute.columbia.edu/videos/watch/509 2014-05-13. 
av extrem torka under hela det nya millenniets första decennium. Torkan och den demografiska stress som följer av brist på mat och vatten gjorde att redan befintliga sociala spänningar ökade mellan ett tiotal olika etniska och religiösa grupperingar i landet, spänningar som i nödtider snabbat blossade upp till dödlig konflikt. En redan hög nivå av social splittring och ojämlikhet med hög arbetslöshet och utanförskap förvärrades. Det geopolitiska spelet om makten i mellanöstern gjorde att utländska krafter grep in, främst en gruppering som leds av USA och stöds av Turkiet och Saudiarabien å ena sidan, med Ryssland och Iran i andra hörnan. Alla skickade de vapen, däribland sådana som tillverkats inte alls så långt ifrån flyktingarnas nya hemorter i Sverige. Bakom tillverkningen av vapen, bakom arbetslösheten och oförmågan att mota en långvarig torrperiod med dyra och tekniskt avancerade medel ligger ett globalt finansiellt och tekniskt subsystem som underkänt Syrien som lämpligt investeringsobjekt. Inom subsystemet kan också rymmas den höga inflationen och arbetslösheten, båda påverkade av globala kapital- och produktionsflöden. Det är dessa fyra subsystem som Sachs menar måste analyseras och förstås, både var och en för sig, men framförallt alla de komplexa och svårbegripliga kopplingarna mellan dem.

Inget av subsystemen är förstås nytt, även om de har alla förändrats under de senaste decenniernas globaliseringsvåg. Extremt komplexa, världsomspännande orsakskedjor låg också bakom 1900-talets två världskrig, inte minst det första. Vad som ändå är utmärkande för vår tid är snabbheten och omfattningen av information och kommunikationer. De elektroniska medierna är snabba och heltäckande, de för oss in i händelsernas centrum, till exempel till kriget i Irak, och ger oss illusionen av att vi själva får se och uppleva verkligheten, om än på tryggt avstånd. Men naturligtvis får vi alltid en förmedlad bild, en bild med en tanke bakom. Någon vill att vi ska se kriget på ett visst sätt. För dem som har makten över de elektroniska medierna är möjligheterna att styra iscensättningen av världshändelser stora, snabba och momentant världsomfattande. Under en tid har det sett ut som om självpubliceringens möjligheter via nya sociala medier skulle kunna ge alternativa vägar att bygga upp och tolka en verklighet på andra, kanske mera demokratiska grunder. Om de internetbaserade informations- och opinionskanalerna där var och en är sin egen journalist och producent $\mathrm{i}$ längden kommer att påverka genomslagskraften hos de etablerade medierna återstår att se; klart är att den som äger medierna kan i hög grad styra världen.

Sachs noterar också hur illa akademin med dess åtskilda discipliner är rustad för att möta den extrema utmaningen att uppnå en förståelse inom dessa subsystem, än mindre emellan dem. Till detta återkommer jag under nästa princip. Men där Sachs försöker få oss att se komplexiteten i händelsekejdorna i vår globaliserade värld just nu, utgår Zygmunt Bauman, inflytelserik polsk samhällsanalytiker verksam i England sedan fyrtio år, istället ifrån ett historiskt perspektiv. Det är med en bred och djupt skeptisk pensel han drar paralleller mellan vår 
tids globalisering och den tidiga kapitalismen i Västeuropa. ${ }^{93}$ Han påminner om hur nationalstater under ett par århundraden mödosamt fick kämpa för att motverka de fördärvliga sociala effekterna av en otyglad laissez-faire-kapitalism. Under den tidiga kapitalismen hade hushållet och företaget skiljts åt och därmed hade också det sociala skyddsnät som familjen och lokalsamhället (visserligen bristfälligt) utgjorde, satts ur spel. Välfärdsstatens framväxt efter andra världskriget var samhällets tämligen framgångsrika svar på hur människors sociala patos kunde institutionaliseras och förse de allra flesta med rimliga levnadsvillkor under en framgångsrik kapitalistisk tillväxt. Staten hade makten över ekonomin i sitt land och kunde lagstifta och omfördela välståndet för att samhället skulle kunna fortsätta fungera på ett acceptabelt sätt. Vad vi ser nu är en andra våg, skriver Bauman, där nationalstater får hushållens tidigare roll: "Det står inte längre i någon stats makt, hur resursstark, tungt beväpnad och kompromisslös den än är, att på egen hand försvara sina valda värden på hemmaplan". Och även om de fattiga länderna i världen blivit rikare de senaste åren - något som Bauman för övrigt inte uppmärksammar i sin argumentering är fördelningen av jordens resurser fortfarande ohållbar. Och framförallt inom de allra flesta länder i världen, inte minst Sverige, har skillnaderna i hur inkomsterna fördelas, stadigt och markant ökat sedan början på 1980-talet. Den globala laissez-faire-ekonomin får svåra konsekvenser för grupper av människor som stadigt står utanför samhället, utan arbete eller framtidshopp. Samtidigt har stora delar av världen under samma period lyft sig ur fattigdom och svält, demokratiseringen har ökat och framförallt har människans upplevelse av att ha makt över sin egen situation ökat rejält i världen som helhet. ${ }^{94}$

Bauman är utan tvekan en av de starkaste kritikerna när det gäller globaliseringen. Han, liksom andra vänsteranalytiker, ser fenomenet som det grundläggande och definierande problemkomplexet för vårt århundrade. Frances Fukayamas vitt omtalade analys från början av 90-talet, The End of History, hade istället en fullständigt motsatt uppfattning och hälsade globaliseringstrenden som "slutpunkten för mänsklighetens ideologiska utveckling och den utbredningen av den västerländska liberala demokratin som mänsklighetens slutgiltiga styrelseskick". ${ }^{95}$ Liknande tankar finns kvar hos den amerikanska ekonomen Daron Acemoglu och hans statsvetarkollega James Robinson som i en

${ }^{93}$ Här refererar jag Baumans ståndpunkter som de uttrycks i hans Collateral Damage. Social ojämlikhet $i$ en global tidsålder (2012), framförallt avsnittet "Från agora till marknad" samt inledningen "Oavsiktliga offer för social ojämlikhet" där han visar att medeltal och medianinkomster inte kan räknas som tecken på ett gott samhälle; inget samhälle är starkare än dess svagaste länk: "den ökande omfattningen av mänskligt lidande som tilldelas statusen "collateral" (marginellt, externt, överflödigt, utanför den legitima politiska agendan) är ett explosivt fält som uppvisar alla tecken på att kunna bli det mest katastrofala av alla de problem mänskligheten kan tvingas möta, hantera och lösa under det innevarande århundradet." (Bauman 2012, s 15)

${ }^{94}$ Se Inglehart $\mathrm{m}$ fl 2008 och resonemanget kring World Values Survey under princip 4 ovan.

95 "the end point of mankind's ideological evolution and the universalization of Western liberal democracy as the final form of human government" (Fukayama 1992.) 
monumental historisk genomgång försöker visa hur det kommer sig att vissa stater lyckas ge sina medborgare ett bra liv, och vissa inte. Why Nations Fail. The Origins of Power, Prosperity and Poverty heter deras bok från 2012. Grundtesen där är att de stater som har kunnat skapa inkluderande (inclusive) politiska och ekonomiska institutioner lyckas väl, medan stater med självberikande eller utsugande (extractive) institutioner, ofta diktaturer, kan möjligen lyckas skapa god tillväxt under en period men i längden är dömda till fattigdom och elände. $\mathrm{Nu}$ finns det en kanske något naiv och oproblematiserad övertygelse i boken om att USA och Sydkorea är i stort sett lyckade samhällen och att grunden för framgången finns i en fri företagsamhet, som har en förutsättning i den privata äganderätten, som i sin tur gör att människor och företag vågar investera i ny teknologi. Därför är det kanske inte så förvånande att den storsäljande boken hyllats som en av årets bästa av både Financial Times, Goldman Sachs och Christian Science Monitor. Man skulle kunna invända att de inkluderande institutionerna inte är inkluderande mer än för en minoritet och att både USA och Sydkorea är extremt ojämlika samhällen där stora delar av ländernas befolkning faktiskt är fattiga och i någon form av utanförskap. Man kan också invända att deras teori bygger på en grov förenkling av den typen som Stephen Gould, vars arbete jag tar upp under nästa princip, kallar "dikotomins dynasti" eller "vår beklagliga vana att beskriva komplexa sammanhang i termer av oförenliga motsatspar". ${ }^{6}$ Acemoglu och Robinson är dock väl medvetna om förenklingsrisken och försvarar sig med att en enkel teori hjälper till att fokusera på huvudlinjer i utvecklingen, som vi behöver upptäcka för att förstå helheten med alla dess avvikelser. Resultatet av ett lands utveckling kommer aldrig att kunna vara förutsägbart därför att så mycket beror på små, till synes obetydliga skillnader och på slumpen. ${ }^{97}$ Icke desto mindre är tesen klart belysande och de många fall de beskriver har en omfattande geografisk och historisk bredd. Det är verkligen ett globalt perspektiv de anlägger, och som sådant ovanligt bland akademiker som oftast föredrar att hålla sig till sitt expertområde och sin egen del av världen. Under hela deras framställning vilar en tanke om globala framsteg mot sant demokratiska stater, oreglerade marknader och oinskränkta privata äganderätter. Även om det inte är slutet på historien som de ser, så är det trots allt en milsvid skillnad mot den globaliserade värld som Bauman och även Beck beskriver.

\section{Världsmedborgaren, hoppet och utopin}

”Tag dig i akt för de kosmopoliter som i sina böcker söker avlägsna plikter men försummar plikterna som ligger närmast"98 skrev Jean-Jacques Rous-

\footnotetext{
96 Gould 2002, s 112.

97 "Small differences and contingency are not just part of our theory; they are part of the shape of history". Acemoglu \& Robinson 2012, s 435.

98 "Distrust those cosmopolitans who search out remote duties in their books and neglect those that lie nearest." från Rousseau 2004 (1762), s 7. "Défiez-vous de ces cosmopolites qui vont
} 
seau i början på upplysningspedagogikens grundtext numero 1 - Emile, från 1762. Och det är nog klokt att ständigt minnas Rousseaus varning när man börjar fundera kring vad högskolans uppgift skulle kunna vara, inte bara i att kartlägga och förstå globaliseringen utan också i att undersöka handlingsvägar för att skapa en bättre värld. Det finns en risk för att idealisten drömmar sig bort till en onåbar utopi och nonchalerar de små stegen som kan tas på hemmaplan. Men det finns också en risk att problemen på hemmaplan är de som upptar hela medvetandet, som utgör gränsen för vad vi orkar tänka på och ta itu med. Först och främst värnar man om den egna och familjens försörjning, hälsa och välstånd; därutöver kan man också i bästa fall ta sig an de system som direkt påverkar de näraliggande livsförhållandena, genom ett engagemang i lokalsamhället och i politiken på kommun- eller riksnivå. Och allt detta är självklart nödvändigt och riktigt. Men i högskolans utbildningar verkar det stanna där, vid förberedelsen för den egna försörjningen och för det egna nationalsamhällets väl. Det finns självklart många goda undantag, med utbildningar som fördjupar globala perspektiv; huvudriktningen inom högskolan, så som jag set den idag, är dock snarare ännu starkare fokus på det ekonomiska resultatet av utbildningen, på kort och lång sikt. Vad skulle det innebära om vi utöver dessa näraliggande perspektiv också på allvar lägger till ett globalt perspektiv på allt vi arbetar med, till exempel genom att ha världsmedborgarskap som ideal?

Jag använder begreppet medborgare ganska flitigt genom hela mitt resonemang, därför att det så väl fångar in det ansvar som vi måste påta oss som samhällsmedlemmar och de rättigheter vi måste försvara och använda för att bidra till vårt samhälles utveckling. Jag har också hävdat att rättigheter inte är nog, de måste förverkligas som handlingsförmågor, och sagt att utbildningen, inte minst den högre utbildningen, har en viktig roll att spela i att stödja utvecklingen av sådana förmågor hos människor. Men vad är då en världsmedborgare? Det finns ju ingen världsstat att vara medborgare i. Det finns inga världspartier att rösta på och bara ett fåtal fungerande globala institutioner. FN med alla sina underavdelningar spelar en viktig roll $i$ att anlägga globala perspektiv men är sällan effektiv när det gäller akuta konflikter eller långsiktiga hållbarhetsperspektiv; medlemsstaterna, framförallt de stora med USA i spetsen, är inte beredda att betala vad det kostar, vare sig i form av ekonomiska bidrag eller genom att offra något av sin nationella suveränitet. Den internationella domstolen i Haag, som också utgör en del av FN, fungerar, men USA och de andra största medlemsstaterna accepterar domsluten bara när det passar. Världsbanken, också en FN-institution, lägger 10 miljarder dollar per år på åtgärder för att utveckla de minst utvecklade ekonomierna, men har ofta anklagats för att dela ut pengarna på sådana sätt och med sådana villkor som främst gagnar USA:s ekonomiska och inte minst ideologiska intressen.

chercher loin dans leurs livres des devoirs qu'ils dédaignent de remplir autour d'eux". http:// classiques.uqac.ca/classiques/Rousseau_jj/emile/emile.html s11 2014-05-15 
Att det inte finns någon världsstat ska vi nog vara glada för - ordet frammanar dystopier som 1984 eller Matrix snarare än utopier. Redan Immanuel Kant insåg att en världsregering skulle leda till antingen världsdiktatur eller ständiga inbördes strider. ${ }^{99}$ Men utan fungerande globala institutioner är det svårt att tänka sig hur man någonsin ska komma till rätta med de stora globala utmaningarna om klimat, konflikt och hållbarhet. Och för att utveckla sådana institutioner krävs att tillräckligt många besinnar sin del i ansvaret för helheten. När man gör det behöver man inte alls avsvära sig sitt nationella medborgarskap och sin nationella identitet utan man kan, när det kniper, inse att uppoffring av någon del av den nationella bestämmanderätten är nödvändig för att nationen ska kunna bestå och utvecklas även i framtiden.

Nej, det är inte en världsstat som världsmedborgaren strävar efter utan snarare en värld reglerad av frivilliga överenskommelser mellan suveräna stater eller kanske ännu hellre mellan suveräna folk. John Rawls, som jag tidigare hänvisat till i mina försök att förstå vad rättvisa är, söker efter en moralfilosofisk grund för världsmedborgarskapet när han skriver att rättvisa och förnuft bör kunna råda mellan folken i olika länder, på samma sätt som mellan individer i en fredlig stat. Det är möjligt att det är en utopi, skriver han, men det är en realistisk utopi. För att uppnå denna realistiska utopi behövs en folkens rätt, a law of peoples. ${ }^{100} \mathrm{Jag}$ kan inte referera hela hans resonemang här men några nyckelbegrepp är anständighet (decency), ömsesidighet (reciprocity) och politisk rättvisa (political justice). Om ett anständigt folk i sina avtal och överenskommelser med andra anständiga folk är övertygat om att villkoren är de mest rimliga och att den andra parten, i egenskap av fria och likvärdiga medborgare, också rimligen tycker det, utan att politisk eller social ställning och maktrelationer får spela in, finns den nödvändiga ömsesidigheten. Nära besläktat med denna ömsesidighet finns också tanken om okunnighetens slöja, the veil of ignorance, det vill säga att man ska fördela världens goda på ett sådant sätt som erkänner att man inte vet vilken del man själv ska fă. Rika stater kan vara morgondagens fattiga. De avtal och institutioner som upprättas mellan folken i en sådan anda kommer också att vara bestående därför att varje generation som själva vuxit upp med dem kommer att se till att de finns kvar. Fred mellan

99 John Rawls citerar Kant och stämmer in i hans bild: "Here I follow Kant's lead in Perpetual Peace (1795) in thinking that a world government - by which I mean a unified political regime with the legal powers normally exercised by central governments - would either be a global despotism or else would rule over a fragile empire torn by frequent civil strife as various regions and peoples try to gain their political freedom and autonomy." (Rawls 1999, s 36)

100 "Folkrätt" är den svenska beteckningen på det som på engelska kallas internationell allmänrätt, public international law. Som vuxen när jag först lärde mig svenska var jag länge smått förvirrad av termen; man kunde tro att folkrätt hängde ihop med folkvett eller folkhem eller något av de många andra sammansättningar med "folk" som är så betecknande för det svenska samhället och den svenska identiteten. Så är det förstås inte: folkrätt som beteckning för internationell rätt, lagen som gäller mellan folken, är en bokstavlig översättning av latinets ius gentium, där gentium, "folkens", stod för alla de utländska folken som inte var romerska medborgare, bland vilka ius civile, civilrätten, istället gällde. 
folken råder därför att anledningarna till krig (utom som självförsvar) inte längre finns $i$ en välfungerande demokrati, där medborgarnas behov i grunden är tillfredsställda. Enväldiga härskare behövde erövra mark och rikedomar, diktera trosbekännelser och skaffa sig mera makt och ära; i en anständig och rättvis demokrati finns inget sådant behov. I ett världssamfund där folkens rätt råder över förnuftiga institutioner finns inte heller massmigrationer därför att orsakerna till dem - förtryck, förföljelse, inbördeskrig, svält - är borta, tack vare den anständiga styrformen inom nationen. Rawls ser också det betryggade ägandet som en garant för att folken, företrädda av sina regeringar, ska vilja vårda och skydda sina tillgångar, sitt land, för evig tid.

Låter det som en utopi? Visst, det är det också och det säger ju Rawls, men det är en utopi som är realistisk, som är nåbar. Det är också en utopi som vi under det senaste århundradet kommit en bit på väg att förverkliga, genom att antalet demokratier som präglas av förnuft, ömsesidighet och rättvisa vuxit $\mathrm{i}$ världen och våldet radikalt minskat ${ }^{101}$ - även om det ännu finns en lång väg kvar att gå.

Det är inte ofta som vi, åtminstone i väst, talar om utopier nuförtiden. Den kommunistiska utopin gick helt över styr och slutade i fruktansvärt våld, krig och massutrotning, liksom de fascistiska utopierna. Den nyliberala utopin med minsta möjliga statsinblandning och en helt fri marknad skördar också sina offer, om än på helt andra sätt. Jag tänker mig alltså världsmedborgarskap som ideal, som en realistisk utopi, som inte kräver att vi omkullstörtar befintliga institutioner utan att vi fullföljer de förnuftiga och anständiga regler som trots allt präglar demokratiska samhällen för att gälla mellan olika folk - och därmed förstås mellan stater - och att vi fortsätter bygga och utveckla globala institutioner med ömsesidighet som princip.

"I vår tid är världsmedborgaren en människa som tar upp nutidens stora och brännande globala problem för att bidra till lösningar som är till gagn för hela mänskligheten", skriver den danske filosofen och pedagogen Peter Kemp i sin plädering för "världsmedborgaren som ideal för bildning och utbildning". ${ }^{102}$ Han är inte nådig mot den danska självnöjdheten och självtillräckligheten och dess uttryck i vad han ser som en terapeutisk, inåtvänd skola, "där allt betydelsefullt ska hämtas från ens inre. Läraren ska inte stå för något, inte vara en förebild. Lärarens kännedom om och erfarenhet av världen ska nämligen inte pådyvlas eleven - det vore 'indoktrinering." 103 Det är inte utan att den svenska högskolan också skulle kunna ta åt sig av hans kritik.

${ }^{101}$ Harvardpsykologen Steven Pinker har i sin bok, The Better Angels of Our Nature. A History of Violence and Humanity (2011) följt den ryckvisa men ändå radikala och konsekventa minskningen av våldet mellan människor genom världshistorien. Bland de skäl han anför återfinns både uppkomsten av nationalstater med ensamrätt på legitimt våld och en växande kosmopolitism, som genom moderna kommunikationer får människor att bättre förstå och sympatisera med folk som är annorlunda än de själva.

102 Kemp 2005, s 17.

${ }^{103}$ Ibid, s 34. 
I den ekologiska medvetenhetens barndom, på 1970-talet, lanserade den tysk-amerikanska filosofen Hans Jonas ett begrepp som jag tycker är både belysande och användbart -"avståndsetik". Redan 1979 gav Jonas ut Ansvarets princip. Utkast till en etik för den teknologiska civilisationen (till svenska 1994). Den grundläggande moraliska principen är den att man måste "handla så att verkningarna av din handling är förenliga med bevarandet av äkta mänskligt liv på jorden" eller, uttryckt som en enkel uppmaning: "Äventyra inte villkoren för mänsklighetens infinita fortbestånd på jorden".104 Denna "plikten till en framtid", som Hans Jonas kallar det, upphöjer han till imperativ, en grundsats som bara måste gälla i alla lägen, av samma slag som Kants kategoriska imperativ: "Handla så att du kan också vilja att din maxim blir allmän lag". Kants imperativ är en "nästa-etik" till skillnad från Jonas avståndsetik, men båda måste gälla samtidigt och komplettera varandra. Grundregeln måste således gälla för andra tider och andra platser än här och nu - men också här och nu. När människan upptäcker att hon skadat naturen, inser hon för första gången i sin långa historia att naturen är sårbar, att hon har makt över den och att hon därför måste ansvara för den. "Alla tidigare föremål för mänskligt handlande framstår som dvärglika gentemot detta", skriver Jonas, och fortsätter: "Närhetens och samtidighetens inhägnad är borta, bortspolad av den rumsliga utbredningen hos och tidslängden i de kausala följder som den tekniska praxisen... sätter igång." ${ }^{105}$ Därtill går inte förändringarna att backa, de är irreversibla. De är därför också kumulativa; i mellanmänskliga relationer kan vi alltid be om förlåtelse, sona våra brott och börja om från början - så inte i människans mellanhavanden med naturen. Det är inte så lite omskakande när det uttrycks så. Ett ansvar för hela mänskligheten i evig tid - det är vad avståndsetiken innebär i förlängningen. Jag kan inte se att det finns väg någon väg runt de två imperativen i förening: handla så att din handling kan upphöjas till allmän lag och så att du skyddar mänsklighetens fortbestånd.

Ett hopplöst läge har vi försatt oss $i$, kan man tycka. Och därför tror jag att vi behöver realistiska utopier också för att ingjuta hopp. Men akademiker och lärare har i allmänhet - och nu är jag verkligen ute och generaliserar, om än utifrån över trettio års umgänge med dem - snarare en viss dragning till cynism och fatalism. Man vill framstå som illusionsfri, aldrig naiv. Det är som om man genom att tro på det värsta skulle kunna avvärja det; genom att säga att ingenting ändå går att påverka, undkommer man sitt eget ansvar att agera. Hopp som begrepp har varit mera förbehållet kyrkan och de kristna dygderna i Paulus tappning: tro, hopp och kärlek. Men en av 1900-talets giganter i den brittiska kulturkritiken, en vars ledsagare snarare varit Karl Marx än Jesus Kristus, nämligen Raymond Williams, har uttryckt vårt behov av hopp så här: "Det är bara genom en vidhålla en gemensam tro att praktiska alternativ finns, som balansen mellan krafter och möjligheter börjar förändras. När vi en gång börjat ifrågasätta det oundvikliga, börjar vi samla ihop våra resurser för en hoppets resa. Och även om det inte finns

104 Jonas 1991 (1979), s 38f.

105 Ibid, s 32. 
några lätta svar, finns det trots allt svåra svar, som både är tillgängliga och upptäckbara. Det är dessa som vi kan lära oss skapa och dela med oss av."106

Hopp har också en viktig roll att spela inom den pragmatiska filosofin, vars företrädare, John Dewey och Richard Rorty, jag haft anledning att vända mig till flera gånger under de olika resonemangen i den här boken. Vad de säger är att vi kan förkasta alla försök att hitta en filosofisk grund för sann kunskap - till exempel Descartes försök att en gång för alla lösa frågan om skillnaden mellan sken och verklighet - och att vi i stället ska ägna oss åt att förstå vilken kunskap som är användbar för en bättre framtid. På så sätt ersätter vi visshet med hopp. ${ }^{107}$ Det är möjligt att vetenskapens sökande efter absolut sanning och visshet låtit det bästa bli det godas fiende. Det är möjligt att med hänvisning till en svåruppnåbar sanning vetenskapen låtit bli att fokusera hoppet som finns i rimliga, godtagbara och fungerande lösningar.

Realistiska utopier ger oss alltså hopp. Egentligen kan man kanske säga att en utopi är en samhällelig motsvarighet till individens hopp. Och som sådan är den ju den det enda realistiska eftersom utopin tar på fullt allvar de möjligheter som finns för en framtid som vi inte kan känna till. Cynikern och fatalisten är inte lika realistiska eftersom de avfärdar eller bortser från dessa möjligheter; de finner sig i det som är eller det som händer, genom slumpens eller andra krafters försorg. Hoppet är en förutsättning för att kunna påverka sin egen framtid, den realistiska utopin en förutsättning för att kunna påverka mänsklighetens och jordens framtid.

Men om vi ska kunna hoppas på sådana realistiska framtider, behöver den högre utbildningen spela en annan och betydligt aktivare roll än den gör idag. Akademiker måste i högre grad än idag rikta in sina ansträngningar på att finna de bästa underlagen för att kunna identifiera och iscensätta lösningar på världens stora problem: rövartåget mot naturen, en växande ojämlikhet mellan människor och en fortsatt extrem fattigdom. Akademiker behöver stå för det de vet och fördöma dem som använder förment vetenskap, dålig vetenskap, för att skaffa sig egen vinning och ställa in sig hos makten. Akademiker behöver bli betydligt bättre på att nå ut med sina avslöjanden av mediernas bjärt målade risker och politikernas populistiska lösningar. Utbildning är ett kraftfullt verktyg och högre utbildning, genom de tilltagande handlingsförmågorna och inre motivationen hos de vuxna studenterna, kanske det mest kraftfulla för att åstadkomma långsiktig samhällsutveckling. Därför anstår det inte den högre utbildningen att vända ryggen mot världsproblemen eller bara ge läpparnas bekännelse i högtidstal och visioner. Alla högskolans utbildningar borde

106 "It is only in a shared belief and insistence that there are practical alternatives that the balance of forces and chances begins to alter. Once the inevitabilities are challenged, we begin gathering our resources for a journey of hope. If there are no easy answers, there are still available and discoverable hard answers, and it is these that we can learn to make and share." (Williams 1983 s 268-9)

107 Se till exempel Rortys båda uppsatser "Truth without Correspondence to Reality" och "Globalization, the Politics of Identity and Social Hope". (Rorty 1999) 
rimligen, utifrån sina olika perspektiv och kunskapsfält, ta sig an förståelsen av de komplext samverkande helheterna: de klimatmässiga, tekno-ekonomiska, socialdynamiska och geopolitiska subsystemen som styr utvecklingen i en globaliserad värld. I avståndsetiken, i världsmedborgarskapet, i folkens rätt finns goda etiska utgångspunkter. Jag kan inte tycka att det är ett orimligt krav att vi inom akademin som fått förmånen att forska och tänka på samhällets bekostnad också tar oss an samhällets stora utmaningar och, med utgångspunkt i våra fördjupningar och specialiseringar, gång efter annan våga lyfta blicken mot de stora, komplexa helheterna. För att kunna göra det behöver man dock erkänna att akademin har betydande strukturproblem. Det finns, bland annat, en djup splittring mellan humanvetenskaperna och naturvetenskaperna och om akademin inte börjar komma till rätta med den, kommer handlingsförlamningen att fortsätta. 